\title{
Teacher Attitudes Toward the Principal of Multilingual Education: Advancing Research on Mother-Tongue Education in Turkey
}

\author{
Hasan Aydin \\ Florida Gulf Coast University \\ Fatma Dogan \\ Yeditepe University
}

\begin{abstract}
The purpose of this study is to examine the attitudes of teacher toward heritage (mother tongue) languages based multilingual education and based on these findings to determine how teachers within public school settings perceive multilingual education. The sample comprised 150 teachers employed in public schools in Turkey. The survey method was used in this study, which used a 5-point Likert-type scale based on the multilingual education attitudes. The scale included 25 items and was prepared through the SurveyMonkey database. The survey was designed to determine the attitudes of teachers on heritagelanguage-based multilingual education and was conducted through the snowball sampling technique on teachers working in public schools in Turkey. A Cronbach's alpha reliability analysis on the data was conducted, and the reliability coefficient of the scale was .968. The results showed the positive attitudes of teachers concerning multilingual education policies.
\end{abstract}

Keywords: multilingualism, mother tongue, multilingual education, heritage language, teacher attitudes, Kurdish, Turkey

\section{Introduction}

Multilingual education demands, migration, and globalization affect the linguistic ecology (Fettes, 2000) of modern 21st-century societies (Aydin \& Cinkaya, 2018; Aydin \& Ozfidan, 2014; Y. Kaya, 2015). Multilingual education helps in developing various language policies that can protect minority rights and cultural values and show respect in a balanced manner with dominant language (Faltis, 2014; I. Kaya \& Aydin, 2013). Multilingual education discussions in Turkey are linked to the history of the Republic of Turkey itself. The linguistic landscape of Turkey was established subsequent to fall of the Ottoman Empire, and Turkey is a state incorporating many former nations. Thus, Turkey, which does not have a homogeneous structure, comprises many different mother tongues (Kalafat, 2017; I. Kaya \& Aydin, 2014).

Humans affect culture and language, and culture and language affect humans (May, 2005; Zeydanlığlu, 2012). Understanding and being understood is achieved through language, which is a prerequisite of the learning and teaching processes that are the essentials of education (Cenoz \& Gorter, 2008; Hornberger, 1991). In addition, Cummins (1991) argued that this communication is possible only via a clear comprehensible language education through a heritage language. When people who have been prevented from using their heritage language or from receiving a heritagelanguage-based education are taught a second language without reaching a necessary proficiency level, then their culture, ethnicity, and language are also denied (Corona et al, 2017; Ĕgitim Sen, 2005; Ilhan \& Aydin, 2015). 
The term heritage language refers to languages that are rich enough to create other languages, that are old and that have extensive content (Szilágyi, Giambo, \& Szecsi, 2013). A heritage language is learned starting from birth and is the language that children acquire from their families, the environment, and the cultural/learning society in which they live without any deliberate learning stages (Fishman, 2001; Gok, 2010; Smith, 2003). In heritage-language-based education, a student studies all courses in his or her heritage language at educational institutions (Lindberg, 2011). Teaching in a heritage language refers to teaching in the mother tongue of the student in a specific course, whereas all other courses are taught in the official language (Aydin, 2013a; Kocak, 2013; Phillipson \& Skutnabb-Kangas, 2012).

Showing respect for a heritage language means showing respect for identity, culture, beliefs, and the past related to that language (Gok \& Derince, 2013; I. Kaya \& Aydin, 2013). However, in Turkey, the official ideology that has predominated for years has often meant either the diminution or the outright suppression of languages other than Turkish and a lack of information on this issue, a subconscious concern for subversion, and separatism have led to discrimination against rather than the rehabilitation of languages (Aydin \& Damgaci, 2017; Can, Gok, \& Simsek, 2013). Researchers have emphasized that learning minority languages in Turkey that are carriers of all the cultures present in country should be encouraged by creating an inclusive and pluralist school culture rather than an exclusivist one (Aydin \& Kaya, 2017; Can et al., 2013; Hassanpour, Skutnabb-Kangas, \& Chyet, 1996). In addition, scholars have indicated that a right for heritage-language-based education is an inevitable outcome of the integrative and modern education models of multi/bilingual language education that must be included in the national curriculum (Ozfidan \& Aydin, 2017; Skutnabb-Kangas \& Fernandes, 2008; Uçarlar, 2009).

Therefore, how are these heritage-language rights to be ensured in Turkey? And when and through what model should the right for heritage-language-based education be transferred to the educational system?

Elective (extracurricular) courses have been included in the curriculum in Turkey since 2012, one of which is "Living Languages and Dialects." As a result, the Kurmanci, Zazazki, Adighebza, Abhazca, and Laz languages were taught to fifth- and sixth-grade students in public school $2 \mathrm{hr}$ per week on the condition that at least 10 students selected the same course. However, many did not believe that these courses met the needs of students. Thus, a fundamental question arises about how these elective courses can be made more effective. In this context, the purpose of this study was to analyze the ongoing discussions on heritage-language-based education and multilingual education in Turkey to determine the attitudes of teachers toward heritage-language-based multilingual education.

\section{Literature Review}

Despite the multicultural sociological structure of Anatolia, heritage-language training and heritagelanguage-based education for languages other than Turkish have not been discussed on a sound basis. Article 42 in the Constitution of the Republic of Turkey (Constitute, n.d.) stated that "No one shall be deprived of the right of education" (p. 22) but added that "No language other than Turkish shall be taught as a mother tongue to Turkish citizens at any institution of education" (p. 23). This contradictory state means that thousands of children who have lost the rights to heritage-languagebased education have been detached from their culture and history (Eğitim-Sen, 2005). DogancayAktuna (1998) argued that

the important societal and linguistic changes of this period in history can shed light on some decisions taken in the new Republic: the Turkish language reform, which had been initiated by the late nineteenth century literary figures, was gaining national attention and turning into an official undertaking. (p. 27) 
Although Turkey has been a homeland for 36 different ethnic minorities and cultures for all of her history (Ilhan \& Aydin, 2015), Turkish has been the only official language in the national educational system for a century. Therefore, minority or heritage languages include indigenous languages that are often endangered and have been in danger of disappearing in Turkey for many years. For instance, Arslan (2015) noted that the Kurdish language was not only ignored but banned from public use and Turkish became the lingua franca for all citizens even through Kurds comprise $20 \%$ to $25 \%$ of Turkey's population (KONDA Research and Consultancy, 2011).

The term heritage language is used to identify languages other than the dominant language (or languages) in a given social context (Kelleher, 2010). In Turkey, Turkish is the dominant and official language used in government and education and public communication; thus, any language other than Turkish can be considered to be a "heritage language" for speakers of that language. Many people in Turkey have cultural connections to and know languages other than Turkish; these include Kurdish (Kurmanji), Assyrian, Zazaki, Arabic, Pomak, Laz, and Romanian, among others (Aydin, 2012b; I. Kaya \& Aydin, 2013). Language, which is a system of sounds and words used to express thoughts, emotions, expectations and designs verbally or in written form, has historical and social value for a person who is living in and has been developing through its unique structure. Cummins (1996) highlighted the importance of affirming the multilingual talents of heritage language learners as a valued component of their identities. Hornberger (2005) noted that "when school contexts reinforce status differentials between home and school languages, students disengage their identities from their home languages and the process of language loss is accelerated" (p. 607).

In addition, Banks $(1988,2014)$ argued that heritage language education has always been a matter of political discussions all around the world. Those who argue that a monolingual educational system and unicultural structure are the most important conditions for the unity of a country often emphasize the idea that bilingual education risks the unity of the country and divides it (Hernández, 2002). In Turkey, the idea of unification of education set forth by the law on unification of education (Constitute, n.d.) has been seen as one of the most important means of ensuring the unity of the country (I. Kaya \& Aydin, 2013). As a result, the failure to develop heritage language/multilingual education by raising the excuse of the political, cultural, and social conditions "peculiar to us" hinders the sociocultural development of the country, negatively affects the quality of education, and leaves many problems, chiefly the language issue, unresolved in Turkey. Language affects the intellectual process with its acts of speaking and creates uniqueness and distinctiveness by building a relationship with meaning, abstraction, image, and a body of lingual rules (Associated Press, 2012; Eğitim-Sen, 2005).

The Universal Declaration of Human Rights (n.d.) stated that "everyone has the right to education" (Article 26), and the acquisition of a heritage language is key component of these rights. According to Unal (2010) and Arslan and Yigit (2016), for education to be identified as a right, a minority group should be able to undergo language development in the same settings, classes, and courses by receiving the same respect as the majority and without undergoing the cultural and identity pressure of the majority group through the organization of multicultural education (Corona et al., 2017). According to Gok (2012), ensuring the right for an education in an educational system can be achieved through removing discrimination based on class, gender, race, ethnic roots, languages, religions, geographical region, political views, and age.

Democratic societies consider that all languages, cultures, and identities are equal to each other (Lafer, 2014; Lafer \& Aydin, 2012). They regard multilingualism as a richness of variety rather than as a threat. They expand this richness in every field of life (Gok, 2012). According to I. Kaya and Aydin (2013), an education is the process of lifelong learning, providing individuals with the necessary information and skill approaches to place them in a more just and equal position in a democratic society. In heritage-language-based multilingual education programs that have various 
bases with respect to linguistic, academic, and socioculture factors, students start being educated in the language they speak at home; they add the other official education language(s) to their repertoire later.

\section{Theoretical Lens}

\section{Submersion Education Model}

The form of school language experience described earlier has often been referred to as immersion (Cohen \& Swain, 1976). The reality of the situation for non-Turkish speakers in Turkish-medium schools is perhaps better reflected in the term submersion rather than immersion. Submersion reflects the sink-or-swim nature of the school experience for a minority group student. Another study found that the form of school language experience, also referred to as immersion, began to appear in many parts of Canada during the 1970s (Swain, 1974) and in several schools in the United States during the 1980s (Kim, Hutchison, \& Winsler, 2015). In this model in which education is given only in the dominant language, the other languages spoken are ignored and only prestigious Western languages are taught as the second language. Linguistic minority communities are obliged to practice monolingualism due to the difficulties encountered in transferring their native language to future generations. Figure 1 shows the model currently used in the Turkish educational system.

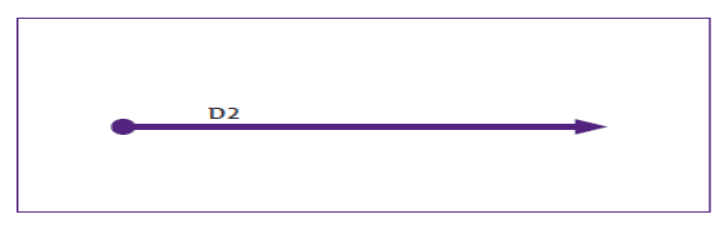

Figure 1. Submersion Education Model. D2 = student's second language (Turkish) for Kurdish children (not mother tongue; Ceyhan \& Kocbas, 2009).

\section{Transitional Educational Model}

The transitional educational model for educating English language learners, and the most common of the truly "bilingual" models in which two languages are actually used in the classroom in the United States (Freeman, 2007) is known as early exit or transitional bilingual education. Vialpando et al. (2005; as cited in Kim et al., 2015) said,

Like the earlier models, these programs focus on helping English language learners acquire English as quickly as possible. Students are instructed in both their native language and English for a few years, but the use of the native language in the classroom is phased out beyond second or third grade. (p. 238)

Although the main purpose of this model is often cited as increasing school success, enabling school attendance, and facilitating and accelerating reading and writing, studies have shown that the main purpose of this model is actually to accelerate assimilation under the banner of integration. In addition, Ochoa and Rhodes (2005) underlined that the reason for the phase out is the belief that students should not be too reliant on their native language throughout formal schooling or they will not become fully proficient in English (Gorter \& Cenoz, 2004; Ochoa \& Rhodes 2005). According to I. Kaya and Aydin (2013), in the transitional model, which is among the weakest bilingual education models, students who have a minority language receive education in their native language for no more than 3 years during their primary school ages. They complete their education in the dominant language. The native language of the students is used as a tool for improving reading and writing and academic skills in the dominant language. See Figure 2. 


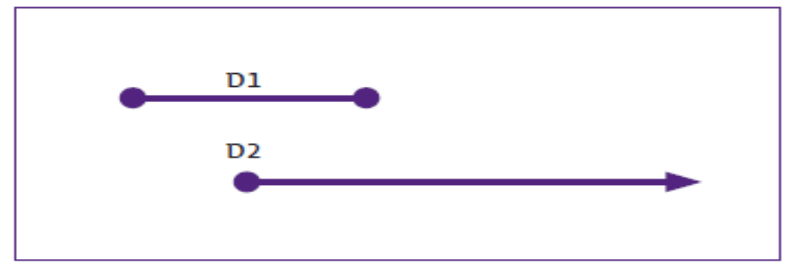

Figure 2. Transitional Educational Model. D1 = student's mother tongue language (Kurdish); D2 = student's second language (Turkish) for Kurdish children (not mother tongue; Ceyhan \& Kocbas, 2009).

\section{Maintenance Educational Model}

According to Cummins (1979), in minority language situations, a prerequisite for attaining a higher threshold, the level of bilingual competence is clearly the maintenance of Language 1 skills. The findings of several research studies suggest that the maintenance of Language 1 skills can lead to cognitive benefits for minority language children. The dominant language or languages are added to the heritage-language-based bi-/multilingual education, which is given between the ages of 6 and 8 , in foreign language or other courses. Dube and Hebert (1975) found that Franco-American children instructed bilingually performed better in English skills than the control children by the end of elementary school. Thus, students use their native languages throughout most education processes to acquire academic competence. This proportion of language instruction is a minimum of $50 \%$. The use of Gaelic in England, Catalan in Spain, and French in Canada are examples of this model (Aydin, 2013). In addition, Hornberger (1996) said that language maintenance strengthened cultural identity and civil right affirmation. See Figure 3.

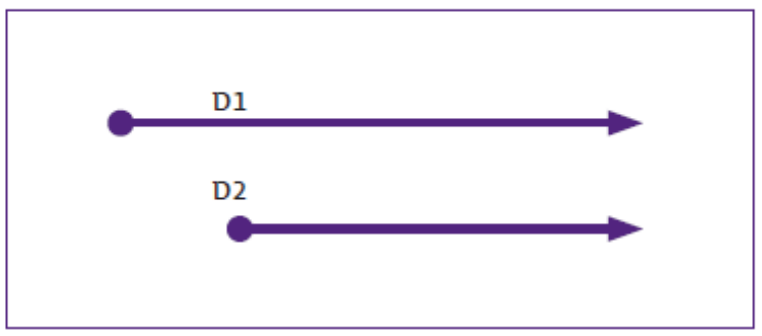

Figure 3. Maintenance Educational Model. D1 = student's mother tongue language (Kurdish); D2 = student's second language (Turkish) for Kurdish children (not mother tongue; Ceyhan \& Kocbas, 2009).

\section{Two-Way Immersion Educational Model}

The two-way immersion educational model uses two languages to reach the same standard level of education as mainstream classrooms (Lindholm-Leary, 2001). This approach provides languageminority students with instruction in their native language for a maximum of 1 year. Following this year, the students are moved into mainstream English classrooms (Garcia \& Curry-Rodriguez, 2000). In this model, students speaking the minority language and the dominant language remain in the same classroom and both languages are used equally. In some schools in America that use this model, students whose native language is Spanish and those whose native language is English are placed in the same classroom. These students are educated by bilingual teachers and learn and start using both languages rapidly. The problem in this model, which yields positive outcomes with respect to academic development and bilingualism, is that it fails to draw sufficient attention from 
the speakers of the dominant language (Derince, 2012; see Figure 4). Such education programs should include various features: (a) considering that all the languages in a country provide richness; (b) granting the right for a heritage language-based education to those whose native languages are different from the dominant language; (c) recognizing social, political, and lingual rights; (d) establishing the necessary conditions for using the native language in formal and informal education; (e) preparing heritage-language-based multilingual education programs; and (f) developing strategies for these programs (Malone, 2012).

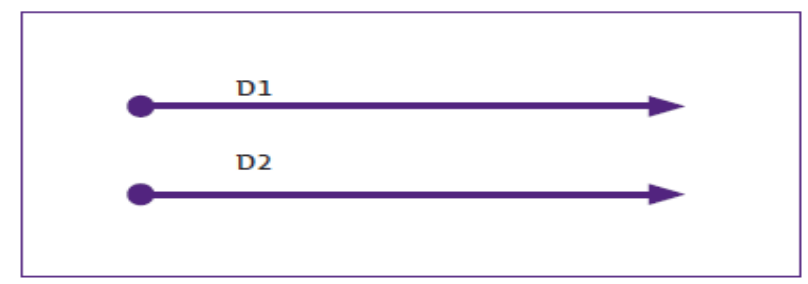

\section{Figure 4. Two-Way Immersion Educational Model. D1 = student's mother tongue language (Kurdish); D2 = student's second language (Turkish) for Kurdish children (not mother tongue; Ceyhan \& Kocbas, 2009).}

Both languages are equal in status and are supported by society in this education model, which the children of families of the middle class mostly prefer. The students receive education in a second language rather than their native language in these schools, and the teachers are competent in both languages and respect the native languages of the students. Languages that are spoken in this model are economically advantageous and do not historically have wide status differences. The French and English bilingualism education programs carried out in Canada is an example for this model. The mother tongue of students is not disparaged in this model, and the heritage language and dominant languages are considered equal in value. When students begin the bilingualism program, their language skills are homogenous. Because no student is at a higher level in grammar and language skills, the chance of encountering a decrease in student self-respect and motivation is minimal (Aydin, 2013). When developing multilingual education strategies, determining the linguistic abilities of language groups of children aged 5 to 6 through sociolinguistic means, preparing language profiles that embrace teachers and children, including multilingual education programs in the educational program, training and employing bilingual teachers, enabling awareness and sensitivity in the society about bilingualism, and developing educational methods for the first and second language are achieved through promoting policies and norms that support these methods and provide resources for them (Miller \& Jhingran, 2012; Y. Kaya, 2015; Yigit \& Tatch, 2017).

Every human thinks and designs in the languages in which she or he learns, and, thus, by reproducing meaning within the "present" scope, a social and individual memory is created. The mother tongue comprises meaning that is transmitted from the past to the future. For this reason, heritage language training is important because it creates and re-creates self-consciousness and puts that consciousness into force. Failing to offer heritage-language-based education leads to a deficiency in socialization, identity disruption, failure to contribute to national values, isolation from the environment, inability to achieve a sense of insecurity, and evaluation of the negative remarks about oneself. Learning the mother tongue is effective in improving knowledge and concepts, permanent reading habits, and critical thinking skills (Ë̆itim-Sen, 2005; Michou, Mouratidis, Ersoy, \& Uğur, 2016). Many experiences worldwide have shown that bilingual education strengthens social peace and facilitates compatibility and compromise by enabling intercultural transmission (Cummins, 1996; Hornberger, 2005; I. Kaya \& Aydin, 2014). Literacy in two languages is possible only through education, in other words, through bilingual education (Baker, 2012). 
To what extent implementing the Living Languages and Dialects course will affect attitudes toward heritage-language-based multilingual education is an issue of concern and has not yet been studied. Teacher perceptions of this issue and the attitudes of school administrators toward the courses and the students who select these courses are subjects that have not been fully examined either. The purpose of this study is to examine the attitudes of teachers toward heritage-language-based multilingual education and, based on these findings, to determine how multilingual education is perceived by teachers within school settings in Turkey. These findings on multilingual education should assist teachers, families, and researchers. Answers for the following questions were sought:

Research Question 1. What are the attitudes of Turkey's public-school teachers on mothertongue-based bilingual education?

Research Question 2. What is the perception of Living Languages and Dialects course teachers on multilingual/bilingual education?

Research Question 3. Based on gender, age, mother tongue, and educational status, do any significant differences exist in teacher attitudes toward heritage-language-based multilingual education?

\section{Method}

This study was conducted using a 5-point Likert-type scale through the descriptive screening model with a quantitative research method. In the descriptive screening model-in which numeric values of a variable are collected, described, and presented - the data collected from a sample or an entire population are used (Buyukozturk, 2011; Creswell, 2009).

\section{Participation and Data Collection}

With respect to this study, the Heritage-Language-Based Multilingual Education Perception Scale was prepared through the SurveyMonkey database and conducted through the snowball method for teachers working in Turkish public schools in the 2013-2014 academic terms. The researchers received permission from Yildiz Technical University's Institutional Review Board to conduct this study (Notice 5821933-302.99-1997, issued in November 2013). Participants were asked to sign a consent form and were informed that their participation in the study was voluntary. The participants were also notified that they could withdraw from the study at any time and that their responses were confidential. The participants comprised 150 teachers ( 83 female and 67 male) who completed the questionnaire prepared for the study. The participants' ages ranged from 23 to 51 years $(M=30.56, S D=3.5)$. The scale prepared during the study data collection stage was sent to various teacher forums in January 2014 and the survey was closed at the end of March.

\section{Data Collection}

The questionnaire used was developed by Dogan and Aydin (2019) and contained two sections. The first section included demographic information (gender, age range, ethnic origin, mother tongue, regions worked in, professional year, and educational status) of the participants, and the HeritageLanguage-Based Multilingual Education Scale was included in the second section. Initially, 26 items were in this scale, using a 5-point Likert-type scale, with potential answers ranging from 1 (very low) to 5 (very high) or from 1 (I strongly disagree) to 2 (I disagree), 3 (I am unsure), 4 (I agree), or 5 (I strongly agree).

Scale items were prepared based on a literature review and various measurement instruments used in different studies (Baker \& Jones, 1998; Damgaci \& Aydin, 2013a; Valdés, 2001). The prospective scale was sent to five expert instructors working in several universities for their opinions. The 
validity and reliability tests of the scale were carried out on these data through SPSS Version 18.00 software. The Kaiser-Meyer-Olkin (KMO) and Bartlett test values were calculated on the data collected for the scale's validity test (see Table 1). A factor analysis was conducted on the data, and item-total correlations and discrimination difficulty ( $t$ test) were identified.

Table 1. Kaiser-Meyer-Olkin (KMO) and Bartlett's Test of Sphericity Values for the Items of the Heritage-Language-Based Multilingual Education Perception Scale for Teachers

\begin{tabular}{lcccc}
\hline & & \multicolumn{3}{c}{ Bartlett's Test of } \\
\cline { 3 - 5 } Measure & KMO & $\boldsymbol{\chi}^{\mathbf{2}}$ & $\boldsymbol{d} \boldsymbol{f}$ & $\boldsymbol{p}$ \\
\hline Heritage-Language-Based & .951 & 36.29 & 325 & .000 \\
Multilingual Education Perception & & & & \\
Scale for Teachers & & & & \\
\hline
\end{tabular}

With respect to the reliability studies, the internal consistency levels and the ability to create stable measurements were tested. A $p<.05$ level was considered sufficient to continue the analyses.

According to the analyses, the KMO value was 0.951, and the Bartlett value was in the $p<.05$ level. Items in the scale were placed under a single factor. The item-test correlation and discrimination difficulty levels of the scale items were significant $(p<.05)$. The Cronbach's alpha reliability coefficient was .968. Thus, the Heritage-Language-Based Multilingual Education Perception Scale can be considered to be a valid and reliable scale.

The KMO coefficients indicated the convenience of the data structure for a factor analysis. The KMO coefficient should be more than .60 for factorability (Buyukozturk, 2011). The results in Table 1 show that the sample was appropriate for developing a scale. A principal components analysis was conducted to determine how many dimensions the scale items were placed under. Figure 5 shows that the items can be placed under a single dimension because a sharp break was present for only one point for the items. After the first point, a highly accelerated fall was present, showing that the scale has a general factor (Aydin \& Aslan, 2016; Buyukozturk, 2011). The figure was examined, and the items were restricted under a single dimension. One item was deleted because it had an item loading value of less than .30 .

The item load values of the Heritage-Language-Based Multilingual Education Perception Scale are given in Table 2. Item loading values of the scale ranged between .321 and .909. In the 25-item scale, Item 8 ("Educational activities carried out in schools should be arranged so as to meet the needs of student groups with different mother tongues") achieved the highest loading value that was .909. Item 25 ("The Living Languages and Dialects is a beginning for heritage-language-based education") received the lowest loading value that was .303. The dimension explained about $58.4 \%$ of the total variance. The Cronbach's alpha value for the 25 -item scale was .968 . This result indicates that the scale is a reliable measurement instrument for measuring the perceptions of heritage-languagebased multilingual education (Buyukozturk, 2011; Karakus, 2018; Toraman, Aydin, \& Ulubey, 2016). 


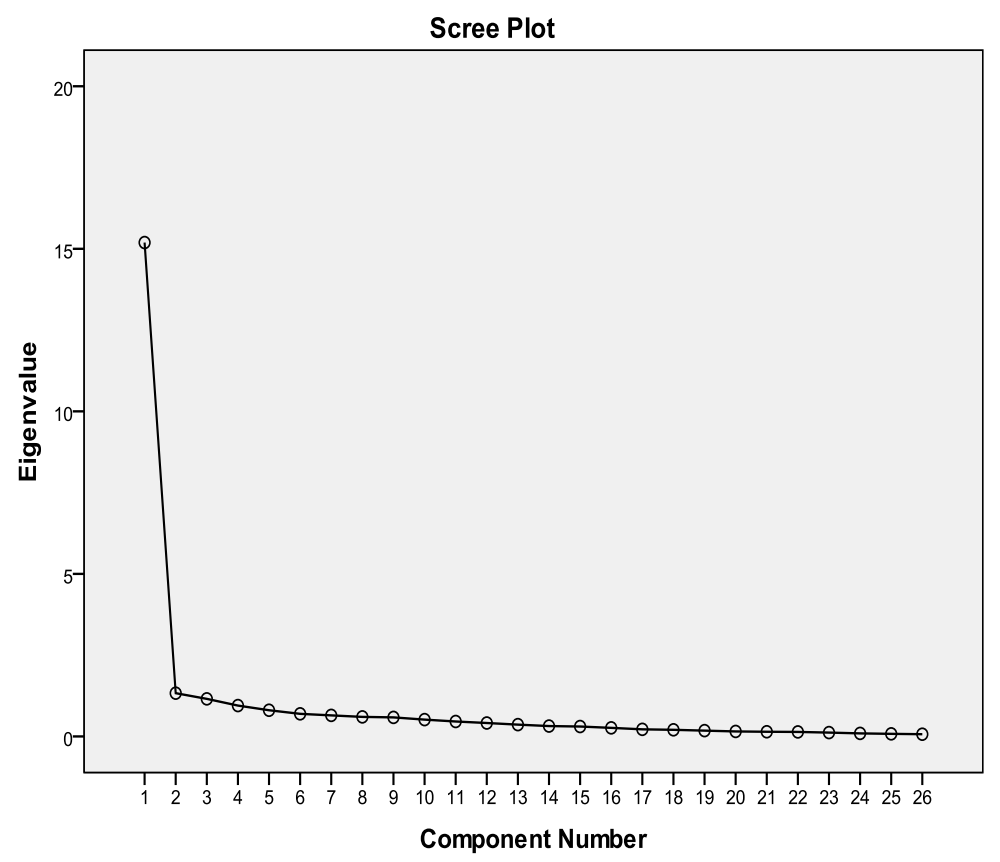

Figure 5. Scree Plot for the Heritage-Language-Based Multilingual Education Perception Scale for Teachers

Table 2. Item Load Values of the Heritage-Language-Based Multilingual Education Perception Scale for Teachers

\begin{tabular}{lc}
\hline Item & Factor Loading \\
\hline $\begin{array}{l}\text { Students who desire can attend to minority schools to learn a second } \\
\quad \text { language. }\end{array}$ & .456 \\
$\begin{array}{l}\text { Students who learn various languages learn to think flexibly. } \\
\text { Bilingual or multilingual education affects academic success of students } \\
\text { positively. }\end{array}$ & .781 \\
$\begin{array}{l}\text { I believe that bilingual education will carry Turkey further under } \\
\text { appropriate social and pedagogical conditions. }\end{array}$ & .756 \\
$\begin{array}{l}\text { Every parent should have the right to demand that his/her child can learn } \\
\text { his/her mother tongue. }\end{array}$ & .881 \\
$\begin{array}{l}\text { Children who cannot use their mother-tongue language have serious } \\
\text { identity formation problems. }\end{array}$ & .882 \\
A teacher has difficulties in the education of students with different & .812 \\
$\quad \begin{array}{l}\text { mother tongues. } \\
\text { kn a disadvantage that students with a different mother tongue do not }\end{array}$ & .540 \\
\hline
\end{tabular}




\section{Data Analysis}

A total of 150 teachers participated in the Heritage-Language-Based Multilingual Education Perception Scale, which was prepared for this study. These 150 teachers filled all the blanks in the demographic information section and the items in the scale. The means of the scale items were examined to determine teacher perceptions on mother-tongue-based multilingual education. These means were interpreted through 0.80 (1.25) intervals $(1.00-1.80=$ very low, $1.81-2.60=$ low, $2.61-$ $3.40=$ medium, $3.41-4.20=$ high, $4.21-5.00=$ very high). The data were analyzed through SSPS Version 18.

The answers that the participants gave for each question were recorded, and the arithmetic mean and standard deviation values were determined to examine the attitudes of teachers concerning heritage-language-based multilingual education. First, the intervals of the results were examined and teacher attitude levels concerning multilingual education were interpreted. Second, whether the independent variables have significant differences on teacher perceptions concerning multilingual education was examined using logistic analysis.

\section{Results}

The data collected through the Heritage-Language-Based Multilingual Education Perception Scale were subject to various analyses, and the findings were identified according to these analyses. Teacher perception levels on multilingual education were determined based on the average scores obtained from the scale. Teacher attitudes toward multilingual education were found to be highly positive. The analysis interpretations of the answers to the research questions are given below.

In reference to Research Question 1, Table 3 shows that the teachers rated the items of the HeritageLanguage-Based Multilingual Education Perception Scale mostly as I agree and I strongly agree. Table 3 indicates that teacher attitudes toward multilingual education were highly positive.

Teacher perceptions of multilingual education can be estimated by taking the arithmetic mean and the standard deviation values of the answers that they gave for the Heritage-Language-Based Multilingual Education Perception Scale items. The arithmetic mean and standard deviation values of the scale items will be given. 
Table 3. Items in the Scale and the Number of Participants $(\mathrm{n}=150)$

\begin{tabular}{|c|c|c|c|c|c|}
\hline Statement & $\begin{array}{l}\text { Strongly } \\
\text { Disagree }\end{array}$ & Disagree & Unsure & Agree & $\begin{array}{l}\text { Strongly } \\
\text { Agree }\end{array}$ \\
\hline I believe multilingual education is necessary. & 13 & 3 & 8 & 25 & 101 \\
\hline $\begin{array}{l}\text { The higher number of languages in a country is an important } \\
\text { indicator of the level of a country's cultural richness. }\end{array}$ & 8 & 5 & 5 & 27 & 105 \\
\hline I find the multilingual studies in Turkey sufficient. & 14 & 8 & 6 & 30 & 92 \\
\hline Teachers should receive education in multilingualism. & 12 & 2 & 7 & 39 & 90 \\
\hline $\begin{array}{l}\text { I believe that the capacity for empathy among students from } \\
\text { different ethnic roots in the classroom will improve with } \\
\text { multilingual education. }\end{array}$ & 10 & 6 & 8 & 40 & 86 \\
\hline $\begin{array}{l}\text { Linguistic structure comprehension skills of multilingual } \\
\text { students develop more than monolingual students. }\end{array}$ & 5 & 5 & 17 & 37 & 86 \\
\hline $\begin{array}{l}\text { For the student to possess self-respect, he or she should receive } \\
\text { education in an environment that respects the mother tongue. }\end{array}$ & 10 & 4 & 4 & 33 & 99 \\
\hline $\begin{array}{l}\text { Educational activities carried out in schools should be arranged } \\
\text { so as to meet the needs of student groups with different } \\
\text { mother tongues. }\end{array}$ & 10 & 6 & 6 & 33 & 95 \\
\hline $\begin{array}{l}\text { Students who desire to should be able to attend minority } \\
\text { schools to learn a second language. }\end{array}$ & 10 & 16 & 13 & 37 & 74 \\
\hline Students who learn various languages learn to think flexibly. & 6 & 6 & 13 & 44 & 81 \\
\hline $\begin{array}{l}\text { Bilingual or multilingual education affects academic success of } \\
\text { students positively. }\end{array}$ & 5 & 6 & 16 & 45 & 78 \\
\hline $\begin{array}{l}\text { I believe that bilingual education will carry Turkey further in } \\
\text { developing appropriate social and pedagogical conditions. }\end{array}$ & 11 & 5 & 9 & 38 & 87 \\
\hline $\begin{array}{l}\text { Every parent should have the right to demand that his/her } \\
\text { child can learn his/her mother tongue. }\end{array}$ & 10 & 4 & 5 & 30 & 101 \\
\hline $\begin{array}{l}\text { Children who cannot use their language well have serious } \\
\text { identity formation problems. }\end{array}$ & 6 & 6 & 8 & 49 & 81 \\
\hline $\begin{array}{l}\text { A teacher has difficulties in the education of students with } \\
\text { different mother tongues. }\end{array}$ & 7 & 5 & 4 & 40 & 94 \\
\hline $\begin{array}{l}\text { It is a disadvantage that students with a different mother } \\
\text { tongue do not know Turkish when they first begin school. }\end{array}$ & 6 & 1 & 6 & 29 & 108 \\
\hline $\begin{array}{l}\text { Students whose mother tongue is not Turkish have the right to } \\
\text { learn and use their own language along with obligatory } \\
\text { Turkish education. }\end{array}$ & 10 & 4 & 5 & 36 & 95 \\
\hline $\begin{array}{l}\text { Education in the mother tongue is a fundamental democratic } \\
\text { right. }\end{array}$ & 8 & 5 & 6 & 24 & 107 \\
\hline $\begin{array}{l}\text { I believe that heritage-language-based education should be } \\
\text { implemented in our country. }\end{array}$ & 11 & 7 & 7 & 26 & 99 \\
\hline $\begin{array}{l}\text { The Ministry of National Education should increase the } \\
\text { number of bilingual teachers for elective language courses. }\end{array}$ & 7 & 3 & 4 & 47 & 89 \\
\hline Everyone who desires to should receive bilingual education. & 8 & 3 & 8 & 41 & 90 \\
\hline All courses should be given in the mother tongue of students. & 18 & 18 & 26 & 27 & 61 \\
\hline Bilingual education courses should be opened in universities. & 8 & 6 & 8 & 43 & 85 \\
\hline $\begin{array}{l}\text { I am uncomfortable with the Living Languages and Dialects } \\
\text { course in schools. }\end{array}$ & 76 & 36 & 23 & 7 & 8 \\
\hline $\begin{array}{l}\text { The Living Languages and Dialects course provokes racism in } \\
\text { schools. }\end{array}$ & 67 & 41 & 29 & 6 & 7 \\
\hline
\end{tabular}


Table 4 shows that the item with the highest mean was Item 16 at 4.547. Among the 150 teachers who answered all the questions in the 25-item scale, six filled in I strongly disagree, one filled in $I$ disagree, six filled in I am unsure, 29 filled in I agree, and 108 filled in I strongly agree for the statement "It is a disadvantage that students with a different mother tongue do not know Turkish when they first begin school."

Table 4 shows that the item with the lowest mean was Item 24 at 1.90 . According to Table 4 , among the 150 teachers who answered to all the 25 questions in the scale, 76 filled in I strongly disagree, 36 filled in I disagree, 23 filled in I am unsure, seven filled in I agree, and eight filled in I strongly agree for the statement "I am uncomfortable with the Living Languages and Dialects course in schools."

When the standard deviation values given in Table 4 are considered, the item with the highest standard deviation was Item 23 at 1.42, and the item with the lowest standard deviation was Item 16 at 0.92 . While the statement "All courses should be given in the mother tongue of the students" in Item 22 had the highest differentiation, the statement "It is a disadvantage that students with a different mother tongue do not know Turkish when they first begin school" in Item 16 had the lowest differentiation. That the standard deviation values were generally high, showing that the teacher group of 150 people had a heterogeneous structure.

Table 5 shows how many teachers were placed in the very low, low, medium, high and very high categories in the Heritage-language-based Multilingual Education Perception Scale. According to this Table 5, 150 teachers completed all items of the survey: five (3.30\%) teachers were in the very low category, five $(3.30 \%)$ teachers were in the low category, eight $(5.30 \%)$ were in the medium category, 50 (33.30\%) were in the high category, and $82(54.60 \%)$ were in the very high category. The category with the most respondents was the high category with $62(54.60 \%)$ teachers. This indicates that the attitudes of the teachers in Turkey toward heritage-language-based multilingual education were high in this sample. 
Table 4. The Arithmetic Mean and Standard Deviation Values of the Heritage-Language-Based Multilingual Education Perception Scale Items (n = 150)

\begin{tabular}{|c|c|c|}
\hline Statement & $M$ & SD \\
\hline I believe multilingual education is necessary. & 4.320 & 1.222 \\
\hline $\begin{array}{l}\text { The higher number of languages in a country is an important indicator of that } \\
\text { country's cultural richness level. }\end{array}$ & 4.440 & 1.077 \\
\hline I find the multilingual studies in Turkey sufficient. & 4.187 & 1.297 \\
\hline Teachers should receive education on multilingualism. & 4.287 & 1.161 \\
\hline $\begin{array}{l}\text { I believe that the capacity for empathy among students from different ethnic roots in } \\
\text { the classroom will improve with multilingual education. }\end{array}$ & 4.240 & 1.157 \\
\hline $\begin{array}{l}\text { Linguistic structure comprehension skills of multilingual students develop more than } \\
\text { monolingual students. }\end{array}$ & 4.293 & 1.020 \\
\hline $\begin{array}{l}\text { In order for the student to possess self-respect, he or she should receive education in } \\
\text { an environment that respects the mother tongue. }\end{array}$ & 4.380 & 1.121 \\
\hline $\begin{array}{l}\text { Educational activities carried out in schools should be arranged so as to meet the } \\
\text { needs of student groups with different mother tongues. }\end{array}$ & 4.313 & 1.159 \\
\hline $\begin{array}{l}\text { Students who desire should be able to attend minority schools to learn a second } \\
\text { language. }\end{array}$ & 3.993 & 1.272 \\
\hline Students who learn various languages learn to think flexibly. & 4.253 & 1.044 \\
\hline Bilingual or multilingual education affects academic success of students positively. & 4.233 & 1.019 \\
\hline $\begin{array}{l}\text { I believe that bilingual education will carry Turkey further under appropriate social } \\
\text { and pedagogical conditions. }\end{array}$ & 4.233 & 1.178 \\
\hline $\begin{array}{l}\text { Every parent should have the right to demand his/her child to learn their mother } \\
\text { tongue. }\end{array}$ & 4.387 & 1.128 \\
\hline $\begin{array}{l}\text { Children who cannot use their language well have serious identity formation } \\
\text { problems. }\end{array}$ & 4.287 & 1.019 \\
\hline A teacher has difficulties in the education of students with different mother tongues. & 4.393 & 1.029 \\
\hline $\begin{array}{l}\text { It is a disadvantage that students with a different mother tongue do not know } \\
\text { Turkish when they first begin school. }\end{array}$ & 4.547 & 0.924 \\
\hline $\begin{array}{l}\text { Students whose mother tongue is not Turkish have the right to learn and use their } \\
\text { own language along with obligatory Turkish education. }\end{array}$ & 4.347 & 1.123 \\
\hline Education in the mother tongue is a fundamental democratic right. & 4.447 & 1.084 \\
\hline $\begin{array}{l}\text { I believe that heritage-language-based education should be implemented in our } \\
\text { country. }\end{array}$ & 4.300 & 1.214 \\
\hline $\begin{array}{l}\text { The Ministry of National Education should raise bilingual teachers for elective } \\
\text { language courses. }\end{array}$ & 4.387 & 0.988 \\
\hline Everyone who desires should receive bilingual education. & 4.347 & 1.049 \\
\hline All courses should be given in the students' mother tongue. & 3.633 & 1.421 \\
\hline Bilingual education courses should be opened in universities. & 4.273 & 1.092 \\
\hline I am uncomfortable with the Living Languages and Dialects course in schools. & 1.900 & 1.151 \\
\hline The Living Languages and Dialects course provokes racism in schools. & 1.967 & 1.108 \\
\hline
\end{tabular}


Table 5. The Number of Teachers in Each Score Interval

\begin{tabular}{lccccc}
\hline Grades and Scores & $\begin{array}{c}\text { Very Low } \\
(\mathbf{1 - 1 . 8 0 )}\end{array}$ & $\begin{array}{c}\text { Low } \\
(\mathbf{1 . 8 1 - 2 . 6 0 )}\end{array}$ & $\begin{array}{c}\text { Medium } \\
\mathbf{( 2 . 6 1 - 3 . 4 0 )}\end{array}$ & $\begin{array}{c}\text { High } \\
(\mathbf{3 . 4 1 - 4 . 2 0 )}\end{array}$ & $\begin{array}{c}\text { Very High } \\
\mathbf{( 4 . 2 1 - 5 )}\end{array}$ \\
\hline $\begin{array}{l}\text { Number of teachers in } \\
\text { the interval }\end{array}$ & 5 & 5 & 8 & 50 & 82 \\
Percentage & $3.30 \%$ & $3.30 \%$ & $5.30 \%$ & $33.30 \%$ & $54.60 \%$ \\
\hline
\end{tabular}

The average score of the teachers obtained from the scale was 4.02. Because the score was in the 3.41-4.20 high category, the attitudes of the teachers in Turkey toward heritage-language-based multilingual education were highly positive.

Research Question 2 asked about the perception of Living Languages and Dialects course teachers on multilingual/bilingual education. Table 6 shows the scores that the teachers gave for the elective language courses under the Living Languages and Dialects course that have given in schools since 2012.

Table 6. Teacher Attitudes Toward the Living Languages and Dialects Course $(\mathrm{n}=150)$

\begin{tabular}{lccccc}
\hline Statement & $\begin{array}{l}\text { Strongly } \\
\text { Disagree Disagree }\end{array}$ & Unsure & \multicolumn{3}{c}{$\begin{array}{c}\text { Agree } \\
\text { Agree }\end{array}$} \\
$\begin{array}{l}\text { Every parent should have the right to demand } \\
\text { that his/her child learn their mother tongue. }\end{array}$ & 10 & 4 & 5 & 30 & 101 \\
$\begin{array}{c}\text { The Ministry of National Education should } \\
\quad \begin{array}{l}\text { develop bilingual teachers for elective } \\
\text { language courses. }\end{array}\end{array}$ & 7 & 3 & 4 & 47 & 89 \\
$\begin{array}{l}\text { I am uncomfortable with the Living Languages } \\
\text { and Dialects course in schools. }\end{array}$ & 76 & 36 & 23 & 7 & 8 \\
$\begin{array}{l}\text { The Living Languages and Dialects course } \\
\text { provokes racism in schools. }\end{array}$ & 67 & 41 & 29 & 6 & 7 \\
\hline
\end{tabular}

In Table 6, the Item 24 statement "I am uncomfortable with the Living Languages and Dialects course in schools" and the Item 25 statement "The Living Languages and Dialects course provokes racism in schools" were negative. Most teachers who participated in the questionnaire marked $I$ strongly disagree for these statements. This shows that a low level of negative attitudes exists toward this course. For Item 25, "The Living Languages and Dialects course provokes racism in schools," 67 of 150 teachers filled in I strongly disagree, 41 filled in I disagree, 29 filled in I am unsure, six filled in I agree, and seven filled in I strongly agree. When considered in general, most participants stated that the Living Languages and Dialects course did not work well for a mothertongue language.

Research Question 3 asked whether-based on gender, age, mother tongue, and educational statusany significant differences exist in teacher attitudes toward heritage-language-based multilingual education. Regression analysis was conducted to see whether variables such as gender, age, mother tongue, educational status, and the region in which someone worked were significant predictors of teacher attitudes toward heritage-language-based multilingual education. 
Table 7. Summary Table of the Multiple Regression Model Where Opinions on Heritage-LanguageBased Multilingual Education Are Used as the Dependent Variable

\begin{tabular}{lccccccc}
\hline Variable & $\boldsymbol{B}$ & $\begin{array}{c}\text { Standard } \\
\text { Error }\end{array}$ & $\boldsymbol{\beta}$ & $\boldsymbol{t}$ & $\boldsymbol{p}$ & $\begin{array}{c}\text { Binary } \\
\boldsymbol{r}\end{array}$ & $\begin{array}{c}\text { Partial } \\
\boldsymbol{r}\end{array}$ \\
\hline $\begin{array}{l}\text { Constant } \\
\text { Gender }\end{array}$ & 5.145 & .300 & & 17.148 & .000 & & \\
$\begin{array}{l}\text { Ethnic } \\
\text { origin }\end{array}$ & -.276 & .116 & -.193 & -2.380 & .019 & -.123 & -.194 \\
$\begin{array}{l}\text { Mother } \\
\text { tongue }\end{array}$ & -.072 & .026 & -.094 & -.872 & .385 & -.253 & -.072 \\
Age & & .031 & -.255 & -2.308 & -.022 & -.269 & -.188 \\
\hline
\end{tabular}

Note. $R=.35, R^{2}=12, F(4,145)=5,075, p=.001$.

Table 7 shows that a significant relationship exists between participant perceptions on multilingual education and their ethnic origins and mother tongues. Gender and mother tongue variables of teachers had a low-level significant relationship with their multilingual education perceptions, $R=$ $.35, \mathrm{R}^{2}=.123, p<.05$. The four variables accounted for $12 \%$ of the total variance concerning the perceptions on multilingual education. Based on the standardized regression analysis coefficient ( $\beta$ ), the relative order of importance of the predictor variables on multilingual education. No significant effect was observed between variables.

According to Table 8, the female mean was 112.30 and male mean was 107.78. This difference was not found to be statistically significant at the $p<.05$ level.

Table 8. Differences of the Attitude Values of the Heritage-Language-Based Multilingual Education Perception Scale According to Gender

\begin{tabular}{lccccc}
\hline Gender & $\boldsymbol{N}$ & $\boldsymbol{M}$ & $\boldsymbol{S D}$ & $\boldsymbol{t}$ & $\boldsymbol{p}$ \\
\hline Female & 83 & 112.30 & 18.05 & 1.267 & .207 \\
Male & 67 & 107.78 & 25.61 & & \\
\hline
\end{tabular}

\section{Discussion and Conclusion}

In this study, which gathered teacher attitudes and determined their perceptions on transferring the heritage-language-based multilingual education to the Turkish educational system, educators expressed that the rights of students to receive education in their mother tongue were not being fulfilled adequately. One rationale for this finding is that the concerns about implementation were due to a lack of information (Coskun, Derince \& Uçarlar, 2010). Filling the information gaps on this issue depends on the multicultural courses given in universities (Damgaci \& Aydin, 2013b; 2014). Mother-tongue training, which is regarded as a topic open to abuse, can be solved only if the dominant groups in a society consider this subject pedagogically.

The findings of previous studies on mother-tongue training in Turkey indicated that teachers have positive attitudes toward this type of education. The Political and Social Research Center (Siyasal ve Sosyal Araştırmalar Merkezi, 2013) conducted a study on "Local elections, social class, ethnicity, Gezi events, ideology, religion, conservatism, migration" in Istanbul and Izmir. A total of 3,944 people, 2,574 from Istanbul and 1,370 from Izmir, were included. Face-to-face interviews were conducted with all the participants at their houses. To determine perspectives on heritage-languagebased education, the participants were asked, "What do you think about the people of different ethnic origins in Turkey receiving education in their mother tongue?" According to the study, 54\% of the population supported heritage-language-based language, $29 \%$ were against heritage-languagebased education, and 17\% neither supported it nor were against it. Gumus's (2010) study found 
similar results. In determining the state of the public regarding heritage-language training and attitudes and opinions toward education in the mother tongue, he found that $69 \%$ of a total of 781 people in 26 different cities belonging to different age, educational status, socioeconomic level, and ethnic groups believed that learning, speaking, and teaching the mother tongue was an unconditional natural right. In addition, the study showed that using multilingual education in curriculum positively contributes to academic success of students who come from a different background other than the dominant language (I. Kaya \& Aydin, 2013).

According to the UNICEF (2016) and Minority Rights Group International, 50\%-70\% of the 100 million children worldwide who cannot attend school speak a language different from the official language of their country. According to the same report, the United Nation's objective of enabling every child worldwide to receive basic education until 2015 was only possible by expanding the rights of the minority to receive an education in their own language (Aydin, 2012a; Aydin \& Koch, 2012; Damgaci \& Aydin, 2018; Keskin, 2010). Enabling children to begin their education through their mother tongue will not prevent them from learning and using the official language or other languages. It has been proven that a gateway for learning other languages well is opened through learning a native language well (Eğitim-Sen, 2005). Brizic (2010) made similar conclusions in her study conducted in six primary schools in Vienna, Austria. The study emphasized that a significant lingual change had occurred in the group participating from Turkey and that they preferred to talk less about their own language. In this study, children in families who preserved their mother tongue got higher marks on tests than those in families who did not. She stated that language was a crucial tool that affects the language competency of the following generation (Brizic, 2010).

According to Cummins (2003), multilingual education has psycholingual foundations that support the academic achievements of students with a minority language. Language skills that are required for academic success go well beyond the knowledge on vocabulary, grammar, and discourse required in daily life. Interlingual academic language competency transference in bilingual children is enabled only when literacy in both languages is supported at school. Supporting additive bilingualism throughout school life and continuing to improve both languages will lead to positive mental and metalingual outcomes. Multilingual education studies and implementations that train teachers on multilingual education should be used for creating education policies that will solve problems related to teaching difficulties that teachers in Turkey face and the comprehension and perception problems that students encounter in the classroom (Alanay \& Aydin, 2016; Alpay, 2010; Aydin, 2013b). Additionally, I. Kaya and Aydin (2013) indicated that Turkey should apply models for multicultural education that are the product of well-thought-out permanent plans and strategies on this topic.

The findings in this study demonstrate that teachers, who are the active implementers of this program, support the heritage-language-based multilingual education program established in Turkey. Many believe that problems related to lingual and cultural rights can be solved through education in the mother tongue. Thus, the Ministry of National Education in Turkey should reform the educational system by taking the positive opinions of teachers on heritage-language-based education into consideration and including them in preparing multilingual education programs.

\section{Limitations of the Study}

There were differences in the number of teachers with respect to ethnic origin in this study. Teachers of Turkish and Kurdish ethnic origins participated in the questionnaire more than the teachers belonging to other ethnic groups because these teachers were unfamiliar with multilingual education models. Because the subject matter was considered to be delicate, some teachers hesitated to fill in the questionnaire. The study could have been enhanced through deep interviews and qualitative methods in addition to the quantitative study. 


\section{References}

Alanay, H., \& Aydin, H. (2016). Multicultural education: The challenges and attitudes of undergraduate students in Turkey. Education and Science, 41, 169-191.

Alpay, N. (2010). Anadili, Yabanci Dil ve Eksiltici İkidillilik [Mother-tongue education, foreign language, and bilingualism]. Ankara, Turikey: Eğitim-Sen Yayinlari.

Arslan, S. (2015). Language policy in Turkey and its effect on the Kurdish language (Unpublished master's thesis). Western Michigan University, Kalamazoo, MI. Retrieved from https://scholarworks.wmich.edu/cgi/viewcontent.cgi?article=1630\&context= masters_theses

Arslan, S., \& Yiğit, M. F. (2016). Investigation of the impact of emotional intelligence efficacy on teachers' multicultural attitudes. Journal of Education and Practice, 7, 147-157.

Associated Press. (2012). Turkey to introduce elective Kurdish lessons (Interview with Pinar Dalkus). Retrieved from http://www.foxnews.com/world/2012/06/12/turkey-to-introduce-electivekurdish-lessons.html

Aydin, H. (2012a). First-generation Turkish immigrants' perceptions on cultural integration in multicultural societies: A qualitative case study. U.S.-China Educational Review B, 2, 326337.

Aydin, H. (2012b). Multicultural education curriculum development in Turkey. Mediterranean Journal of Social Sciences, 3, 277-286.

Aydin, H. (2013a). Dunyada ve Turkiye'de Cokkulturlu Eğitim Tartismalari ve Uygulamalari [Discussions and practices of multicultural education in Turkey and the world]. Ankara, Turkey: Nobel Yayinlari.

Aydin, H. (2013b). Literature-based approaches on multicultural education. The Anthropologist, 16, $31-44$.

Aydin, H. \& Aslan, D. (2016). Reliability and validity testing of a new scale for measuring attitudes toward pedagogical teacher training. Journal of Education and Learning, 5, 1-9.

Aydin, H., \& Cinkaya, M. (2018). Global citizenship education and diversity (GCEDS): A measure of students' attitudes related to social studies program in higher education. Journal of Multicultural Education, 12, 221-236. doi:10.1108/JME-05-2017-0030

Aydin, H., \& Damgaci, F. K. (2017). From empire to republic: Citizenship, pluralism, and diversity in Turkey. In J. A. Banks (Ed.), Global migration, structural inclusion, and education across nations (pp. 351-376). Washington, DC: American Educational Research Association Press.

Aydin, H., \& Kaya, Y. (2017). Educational needs and barriers for Syrian refugee Students in Turkey: A qualitative case study. Intercultural Education, 28, 456-473.

Aydin, H., \& Koch, C. (2012). Romanian second language learners of English requests and apologies. Theory and Practice in Language Studies, 2, 233-239.

Aydin, H., \& Ozfidan, B. (2014). Perceptions on mother tongue (Kurdish) based multicultural and bilingual education in Turkey. Multicultural Education Review, 6, 51-79.

Baker, C. (2012). Ciftdilliligin Gelecegi Var mi? [Does bilingualism have a future?]. Diyarbakir, Turkey: Disa Yayinlari.

Baker, C., \& Jones, S. P. (1998). Encyclopedia of bilingual education and bilingualism. Clevedon, United Kingdom: Multilingual Matters.

Banks, J. (1988). Multiethnic education (2nd ed.). Boston, MA: Allyn \& Bacon Press. 
Banks, J. (2014). Introduction to multicultural education (H. Aydin, Trans.). Ankara, Turkey: Ani Yayincilik.

Brizic, K. (2010). Eğitim Hakki Baglaminda Anadilinde Eğitim (Education in the mother-tongue). Ankara, Turkey: Eğitim-SenYayinlari.

Buyukozturk, S. (2011). Veri Analizi El Kitabi [Data analysis]. Ankara, Turkey: Pegem Akademi.

Can, B., Gok, F., \& Simsek, S. (2013). Toplumsal Barisin Insaasinda Ogretmenlerin Rolu: Kurt Meselesi Okula Nasil Yansiyor? [The Role of Teachers in the Building of Social Peace: How the Kurdish Question Reflects on School]. Istanbul, Turkey: Helsinki Yurttaslar Dernegi.

Cenoz, J., \& Gorter, D. (2006). Linguistic landscape and minority languages. The International Journal of Multilingualism, 3, 67-80.

Cenoz, J., \& Gorter, D. (2008). Linguistic Landscape as an additional source of input in second language acquisition. International Review of Applied Linguistics in Language Teaching, 46, 257-276. doi:10.1515/IRAL.2008.012

Ceyhan, A. M., \& Kocbas, D. (2009). Çiftdillilik ve Eğitim [Bilingualism and Education]. Istanbul, Turkey: Sabanci University Press.

Cohen, A., \& Swain, M. (1976). Bilingual education: The "immersion" model in the North American context. TESOL Quarterly, 10, 45-53.

Constitute. (n.d.). Turkey's Constitution of 1982 with amendments through 2017. Retrieved from https://www.constituteproject.org/constitution/Turkey_2017.pdf?lang=en

Corona, R., Velazquez, E., McDonald, S., Avila, M., Neff, M., Iglesias, A., \& Halfond, R. (2017). Ethnic labels, pride, and challenges: A qualitative study of Latinx youth living in a new Latinx destination community. Journal of Ethnic and Cultural Studies, 4, 1-13.

Coskun, V., Derince, M. S., \& Uçarlar, N. (2010). Dil Yarasi: Ĕgitimde Anadilinin Kullanilmamasi ve Kurt Ogrencilerin Deneyimleri [Language Scare: The ban of Kurdish language and Kurdish students' experiences]. Diyarbakir, Turkey: Disa Yayinlari.

Creswell, J. W. (2009). Research design: Qualitative, quantitative, and mixed methods. Thousand Oaks, CA: Sage.

Cummins, J. (1979). Linguistic interdependence and the educational development of bilingual children. Review of Educational Research, 49, 222-251.

Cummins, J. (1991). Language development and academic learning. Clevedon, United Kingdom: Multilingual Matters.

Cummins, J. (1996). Negotiating identities: Education for empowerment in a diverse society. Ontario, CA: California Association for Bilingual Education.

Cummins, J. (2003). Bilingual education. In J. Bourne \& E. Reid (Eds.), Language education: world yearbook of education (pp. 3-19). London, United Kingdom: British Library Cataloguing in Publishing Data.

Damgaci, F. K., \& Aydin, H. (2013a). Faculty members' perception on multicultural education. Electronic Journal of Social Sciences, 12, 325-341.

Damgaci, F. K., \& Aydin, H. (2013b). Türkiye'deki Eğitim Fakültelerinde Görev Yapan Akademisyenlerin Çokkültürlü Eğitime Ilişkin Görüşleri [Academic opinions on multicultural education in the faculty of education in Turkey]. Dicle Üniversitesi Ziya Gökalp Eğitim Fakültesi Dergisi, 21, 314-331.

Damgaci, F. K., \& Aydin, H. (2014). An analysis of academicians' perceptions of multicultural education: A Turkish experience. The Anthropologist, 18, 817-833. 
Damgaci, F. K., \& Aydin, H. (2018). What we can learn about multicultural education from Social Media. EURASIA Journal of Mathematics, Science and Technology Education, 14, 797-810. doi:10.12973/ejmste/80945

Derince, M. S. (2012). Eğitimde Anadilinin Kullanilmasi ve Kullanilan Modeller? [Use of mother tongue in education and used models]. Diyarbakir, Turkey: Disa Yayinlari.

Dogan, F., \& Aydin, H. (2019). Initial development and validation of the multilingual education scale. International Journal of Educational Research, 28, 376-389. doi:10.1177/1056787919856743

Dogancay-Aktuna, S. (1998) The spread of English in Turkey and its current sociolinguistic profile. Journal of Multilingual and Multicultural Development, 19, 24-39. doi:10.1080/01434639808666340

Dube, N. C., \& Herbert, G. (1975). Evaluation of the St. John Valley Title VII bilingual education program, 1970-1975. Unpublished report, Madawaska, ME.

Eğitim-Sen. (2005). 4. Demokratik Eğitim Kurultayi, 1-5 Aralik 2004 [4th Democratic Education Conference]. Ankara, Turkey: Author.

Faltis, C. (2014). Toward a race radical vision of bilingual education for Kurdish users in Turkey: A Commentary. Journal of Ethnic and Cultural Studies, 1, 1-5.

Fettes, M. T. (2000). The linguistic ecology of education (Unpublished doctoral dissertation). The University of Toronto, Toronto, Canada. Retrieved from https://www.collectionscanada.gc.ca/obj/s4/f2/dsk1/tape3/PQDD_0021/NQ53878.pdf

Fishman, J. (2001). 300-Plus years of heritage language education in the United States. In J. K. Peyton, D. A. Ranard, \& S. McGinnis (Eds.), Heritage languages in America: Preserving a national resource (pp. 81-89). Washington, DC: Center for Applied Linguistics and Delta Systems.

Freeman, R. (2007). Reviewing the research on language education programs. In O. Garciá \& C. Baker (Eds), Bilingual education: An introductory reader (pp. 3-18). Tonawanda, NY: Multilingual Matters.

Garcia, E. E., \&. Curry-Rodriguez, J. E. (2000). The education of limited English proficient students in California schools: An assessment of the influence of Proposition 227 in selected districts and schools. Bilingual Research Journal 24, 1-21.

Gok, F. (2010). Eğitim hakki baglaminda anadilinde Eğitim [Education in the mother tongue education]. In F. Gok (Ed.), Uluslararasi Katilimli Ana Dili Sempozyumu 2 Bildiriler Kitabi [Proceedings of the International Participation Main Language Symposium 2 Proceedings] (pp. 73-93). Ankara, Turkey: Eğitim-SenYayinlari.

Gok, F. (2012). Eğitim hakki baglaminda anadilinde Eğitim [Education in native language education]. Eğitim Bilim Toplum, 10, 10-20.

Gok, F., \& Derince, S. (2013). Cokdilli Eğitim Yoluyla Toplumsal Adalet [Social justice trough multilingual education]. Ankara, Turkey: Eğitim Sen Yayinlari.

Gorter, D., \& Cenoz, J. (2004, September). Linguistic landscapes and L2 learners in multilingual contexts. Paper presented at the European Second Language Association Conference (EUROSLA). San Sebastian/Donostia, Basque Country, Spain.

Gumus, A. (2010). Eğitimde anadilinin kullanimi ve cifdilli Eğitime dair halkin tutum ve gorusleri [The use of bilinligualism in education and the attitudes of bilingual education]. Eğitim Bilim Toplum Dergisi, 10, 52-75. 
Hassanpour, A., Skutnabb-Kangas, T., \& Chyet, M. (1996). The non-education of Kurds: A Kurdish perspective. International Review of Education, 42, 367-379.

Hernández, R. A. (2002). Indigenous law and identity politics in Mexico: Indigenous men's and women's struggles for a multicultural Nation. Political and Legal Anthropology Review, 24, 90-109.

Hornberger, N. H. (1991). Extending enrichment bilingual education: Revisiting topologies and redirecting policy. In O. Garcia (Ed.), Bilingual education (pp. 215-234). Philadelphia, PA: John Benjamins Press.

Hornberger, N. H. (1996). Language and education. In S. L. McKay \& N. H. Nornberger (Eds.), Sociolinguistics and language teaching (pp. 449-473). New York, NY: Cambridge University Press.

Hornberger, N. H. (2005). Opening and filling up implementational and ideological spaces in heritage language education. The Modern Language Journal, 89, 605-609.

Ilhan, D., \& Aydin, H. (2015). Perceptions of higher education faculty members on bilingual education in Turkey. Journal of Education and Training Studies, 3, 146-163

Kalafat, H. (2017). Living languages and dialects: Right to mother tongue education. Retrieved from https://m.bianet.org/english/society/183850-living-languages-and-dialects-right-to-mothertongue-education

Karakus, M. (2018). The moderating effect of gender on the relationships between age, ethical leadership, and organizational commitment. Journal of Ethnic and Cultural Studies, 5, 7484.

Kaya, I., \& Aydin, H. (2013). Turkiye’de Anadilde Eğitim Sorunu: Zorluklar, Deneyimler ve Iki Dilli Eğitim Modeli Oneriler [Native issues in education in Turkey: Challenges, experiences and bilingual education model ideas]. Istanbul, Turkey: Ukam Yayinlari.

Kaya, I., \& Aydin, H. (2014). Pluralism, multiculturalism and bilingual education [Çoğulculuk, Çokkültürlü ve İkidilli Eğitim]. Ankara, Turkey: Ani Press.

Kaya, Y. (2015). The opinions of primary school, Turkish language and social science teachers regarding education in the mother tongue (Kurdish). Journal of Ethnic and Cultural Studies, 2, 33-46.

Kelleher, A. (2010). What is a heritage language? Retrieved from http://www.cal.org/heritage/pdfs/briefs/What-is-a-Heritage-Language.pdf

Keskin, E. (2010). Dunyada da resmi dil, anadillere karsi [Official language in the world, against native languages]. Reviewed from http://www.radikal.com.tr/dunya/dunyada_da_resmi_dil_anadillere_karsi-1027977

Kim, Y. K., Hutchison, L. A., \& Winsler, A. (2015). Bilingual education in the United States: An historical overview and examination of two-way immersion. Educational Review, 67, 236252.

Kocak, M. (2013). Cokkulturluluk Acisindan Dil Haklari [Language rights from multiculturalism]. Istanbul, Turkey: Liberte Yayinlari.

KONDA Research and Consultancy. (2011). Kürt Meselesi'nde Algl ve Beklentiler (Perceptions and expectations in the Kurdish question). Istanbul, Turkey: Iletişim Yayınları.

Lafer, S. (2014). Democratic design for the humanization of education. Journal of Ethnic and Cultural Studies, 1, 6-12.

Lafer, S., \& Aydin, H. (2012). Educating for democratic societies: Impediments. Journal of Social Studies Education Research, 3, 45-70. 
Lindberg, I. (2011). Cok dilli Eğitim: Isvec'ten bir perspektif [Multicultural education: A perspective from Sweden. In M. Carlson, A. Rabo, \& F. Gok (Eds.), Cokkulturlu toplumlarda Eğitim [Education in multicultural societies] (pp. 71-90). Istanbul, Turkey: Istanbul Bilgi Universitesi.

Lindholm-Leary, K. J. (2001). Dual language education. Clevedon, United Kingdom: Multilingual Matters.

Malone, S. (2012). Eğitimde Dillerarasi Kopru Kurmak [Interdisciplinary education]. Diyarbakir, Turkey: Disa Yayinlari.

May, S. (2005). Language rights: Moving the debate forward. Journal of Sociolinguistics, 9, 319-347.

Michou, A., Mouratidis, A., Ersoy, E., \& Uğur, H. (2016). Social achievement goals, needs satisfaction, and coping among adolescents. Personality and Individual Differences, 99, 260265.

Miller, V., \& Jhingran, D. (2012). Hindistan'da Dilsel Cesitlilik ve Dil Politikalari [Linguistic and language policy in India]. Diyarbakir, Turkey: Disa Yayinlari.

Ochoa, S. H., \& Rhodes, R. L. (2005). Assisting parents of bilingual students to achieve equity in public schools. Journal of Educational and Psychological Consultation, 16, 75-94.

Ozfidan, B., \& Aydin, H. (2017). Prospects for bilingual education curriculum in Turkey: A mainstream issue. Higher Education Studies, 7, 25-34.

Phillipson, R., \& Skutnabb-Kangas, T. (2012). Getting language rights right: A response to Makoni. Journal of Multicultural Discourses, 7, 29-35.

Siyasal ve Sosyal Araştırmalar Merkezi. (2013). Secmenlerin Toplumsal Profili Ve Siyasal Egilimleri Sinif, Toplumsal Cinsiyet, Etnisite, Din, İdeoloji Ve Gezi Olaylari [Social profiles and political tendencies of public voters class, gender, ethnicity, religion, ideology]. Istanbul, Turkey: Author.

Skutnabb-Kangas, T., \& Fernandes, D. (2008). Kurds in Turkey and in (Iraqi) Kurdistan: A comparison of Kurdish educational language policy in two situations of occupation. Genocide Studies and Prevention, 3, 43-73.

Smith, R. (2003). Mother tongue education and the law: A legal review of bilingualism with reference to Scottish Gaelic. International Journal of Bilingual Education and Bilingualism, 6, 129145 .

Swain, M. (1974). French immersion programs across Canada: Research findings. The Canadian Modern Language Review, 31, 117-129.

Szilágyi, J., Giambo, D., \& Szecsi, T. (2013). Teaching strategies: "What if I don't speak it?” Classroom strategies to nurture students' heritage languages. Childhood Education, 89, 117121.

The Universal Declaration of Human Rights. (n.d). Preamble. Retrieved from file://C:/Users/haydin/AppData/Local/Microsoft/Windows/INetCache/Content.Outlook/ITOM GS2T/Universal\%20Declaration\%20of\%20Human\%20Rights_.pdf

Toraman, C., Aydin, H., \& Ulubey, O. (2016). Exploring teacher candidates' attitudes towards pedagogical teacher training based on different variables. International Education Studies, 9, $74-86$.

Uçarlar, N. (2009). Between majority power and minority resistance: Kurdish linguistic rights in Turkey (Lund Political Studies Vol. 157). Lund, Sweden: Lund University Press. Retrieved from http://lup.lub.lu.se/search/ws/files/4283150/1486821.pdf 
Unal, I. (2010). Cokkulturlulugu Hak Temelinde Anlamlandirmak: Eğitimde Cokkulturluluk İcin Bir Cerceve [Multiculturalism based on rights]. Ankara, Turkey: Eğitim-SenYayinlari.

UNICEF. (2016). The impact of language policy and practice on children's learning: Evidence from Eastern and Southern Africa. Retrieved from https://www.unicef.org/esaro/UNICEF(2016)LanguageandLearningFullReport(SingleView).pdf

Valdés, G. (2001). Heritage language students: Profiles and possibilities. In J. K. Peyton, D. A. Ranard, \& S. McGinnis (Eds.), Heritage languages in America: Preserving a national resource (pp. 37-77). Washington, DC: Center for Applied Linguistics and Delta Systems.

Vialpando, J. J., Yedlin, C., Linse, M., Harrington, M., \& Cannon, G. (2005). Educating English language learners: Implementing instructional practices. Providence, RI: National Council of La Raza and the Education Alliance at Brown University. Retrieved from https://www.brown.edu/academics/education-alliance/sites/brown.edu.academics.educationalliance/files/publications/edells_impinstprct.pdf

Yigit, I. H., \& Tatch, A. (2017). Syrian refugees and Americans: Perceptions, attitudes and insights. American Journal of Qualitative Research, 1, 13-31.

Zeydanlıŏlu, W. (2012). Turkey's Kurdish language policy. International Journal of the Sociology of Language, 217, 99-125. doi:10.1515/ijsl-2012-0051

The Journal of Educational Research and Practice provides a forum for studies and dialogue that allows readers to better develop social change in the field of education and learning. Journal content may focus on educational issues of all ages and in all settings. It also presents peer-reviewed commentaries, book reviews, interviews of prominent individuals, and additional content. The objectives: We publish research and related content that examines current relevant educational issues and processes aimed at presenting readers with knowledge and showing how that knowledge can be used to impact social change in educational or learning environments. Additional content provides an opportunity for scholarly and professional dialogue regarding that content's usefulness in expanding the body of scholarly knowledge and increasing readers' effectiveness as educators. The journal also focuses on facilitating the activities of both researcher-practitioners and practitioner-researchers, providing optimal opportunities for interdisciplinary and collaborative thought through blogging and other communications.

Walden University Publishing: http://www.publishing.waldenu.edu 